
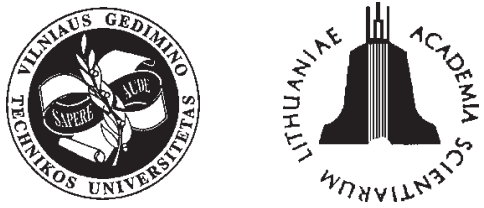

ISSN 1392-3730 print / ISSN 1822-3605 online

JOURNAL OF CIVIL ENGINEERING AND MANAGEMENT

http:/www.jcem.vgtu.lt

2006, Vol XII, No 1, 43-49

\title{
OVERALL EVALUATION OF INDOOR CLIMATE AND ENERGY FOR ALTERNA- TIVE OFFICE DESIGNS USING THE ECO-FACTOR
}

\author{
Erik Bjørn and Henrik Brohus ${ }^{1}$ \\ Dept of Civil Engineering, Aalborg University, \\ Sohngaardsholmsvej 57,DK-9000 Aalborg, Denmark.1E-mail: hb@bt.aau.dk \\ Received 26 June 2005, accepted 18 Dec 2005
}

\begin{abstract}
To facilitate the decision-making and communication, an evaluation method has been devised that incorporates environmental effects of the energy use with thermal and atmospheric indoor climate in a score on an absolute scale from $0-100 \%$, called the "Eco-factor". This factor is based on indicators of physical properties. For the indoor climate part these include mainly the indoor temperature, velocity, and concentration fields. The energy part considers the energy distributed to energy sources, and the environmental effects of the resulting airborne emissions evaluated by Life Cycle Assessment (given by default figures from a database). The tool is used to make an overall assessment of the quality of design alternatives, where the "costs" (energy) is compared to the "benefit" (indoor climate), and to identify possibilities for improvement. The paper shows a model case study of an office building, where choices are considered that must be made in an early design phase.
\end{abstract}

Keywords: assessment tools, indoor climate, energy use, integrated design, environmental impact, decision-making, Eco-factor.

\section{Introduction}

Problems in office buildings are often related to the design and control of the indoor environment and of the building as an energy system. The often interconnected nature of the above two issues is important to take into account, since, for instance, internal and external heat loads, temperatures, and air change rates affect both the energy use and indoor comfort. Thus, to avoid the indoor climate problems that are seen all too often in contemporary office buildings, it is essential that energy optimisation is integrated with assessment of indoor climate. Improvements on one issue are only wanted if it does not have detrimental effects on the other. Examples: 1) Large glazed facades facing south to improve passive solar energy may lead to overheating problems in summer, which again may lead to electricity use due to extra-cooling demand. 2) Natural ventilation used to decrease electricity use may lead to an inadequate indoor air quality when the difference between indoor and outdoor pressure is too small for providing sufficient driving forces. In the following, a few examples illustrate how the Eco-factor tool presents results, and how it can be used as a decision tool in the design process.

\section{Methods}

An evaluation method has been devised that incorporates environmental effects of energy use with thermal and atmospheric indoor climate in a score on a common scale from $0-100 \%$, called the Eco-factor [1-4]. The method in its present form is intended specifically for design of European office buildings, but the underlying principles could be adopted for other types of buildings. Only the operative phase of the building life cycle is considered, since with contemporary building style and energy supply, this accounts for the majority of the environmental effects [2, 5]. Indoor climate aspects are considered that are closely inter-related with energy use: Thermal comfort and Indoor Air Quality (IAQ). The environmental effect of energy use is estimated on the basis of airborne emissions and the related impact, resulting from an LCA of the energy sources.

The Eco-factor is calculated by scoring functions based on physical properties, comprising operative energy use, choice of energy sources, and prediction of indoor temperatures, airflow, contaminant transport etc. The tool is meant to supply an overview of the effects of changing key parameters as room height, air change rate, internal loads, energy source etc. This facilitates rapid iterations, showing potential for improvements on either energy use or indoor climate, but at the same time highlighting perhaps unforeseen dangers, for instance, of compromising indoor climate in order to improve the energy performance.

By explicit weighting in Fig 1 is meant that the relative importance of an impact is described by an explicit 


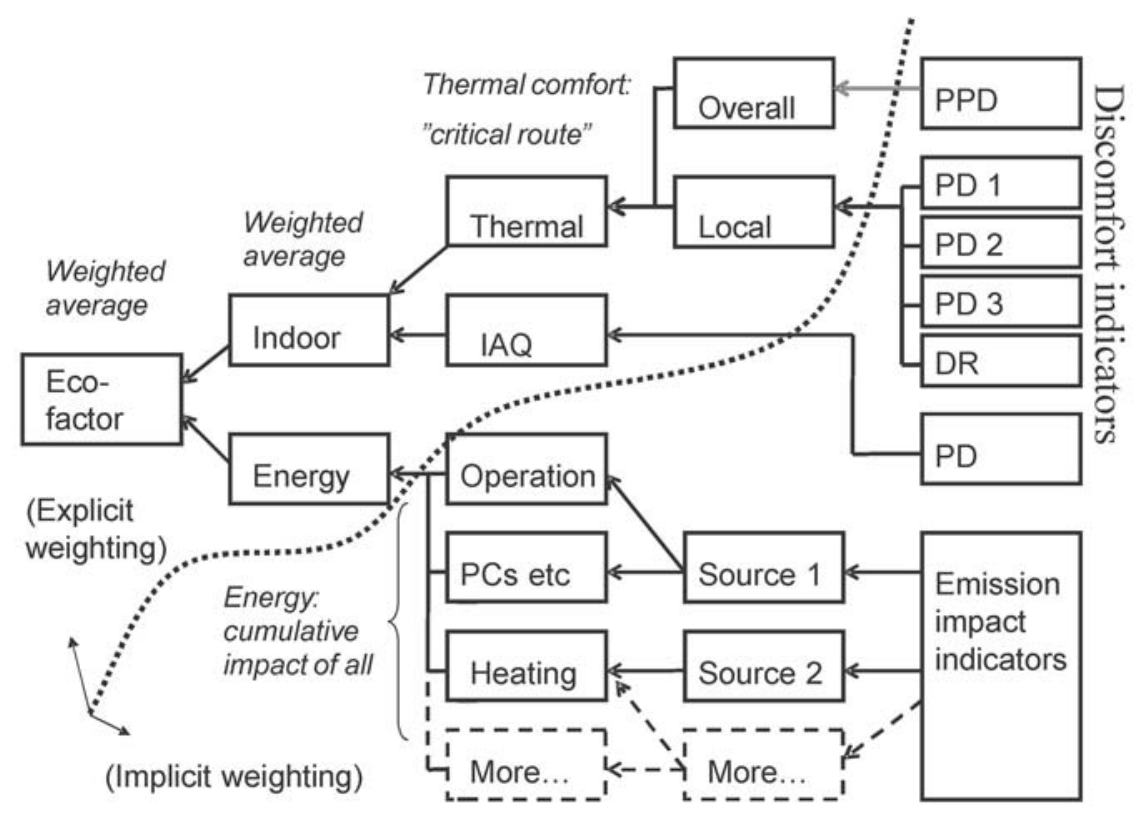

Fig 1. The hierarchical structure of the evaluation method of the Eco-factor. The arrows indicate flow of information. PPD, $\mathrm{PD}$ and DR are discomfort indicators $[6,7]$

weighting factor, for instance, 50/50 for different equally important impacts. Implicit weighting means that weighting or evaluation is taking place in the definition of the indicators, for instance, in the evaluation of certain air temperatures, velocities, and indoor contaminant concentrations in terms of dissatisfaction with the indoor climate; or in the assessment of the seriousness of different airborne emissions, leading to impact indicators.

For calculation of occupants' overall thermal balance, environmental parameters include operative temperature (weighted sum of air and mean radiant temperatures), mean air velocity, and relative humidity. Human factors include activity and clothing. Even if the body is in thermal balance as a whole, it is possible to be uncomfortable due to local cooling or heating of parts of the body. The effects include draught, vertical air temperature difference, radiant temperature asymmetry, and warm or cold floors.

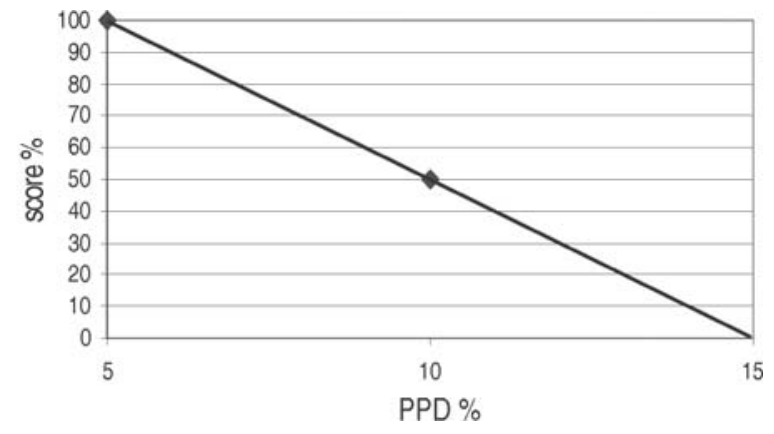

The above-mentioned traditional indicators are transformed to a uniform scale by means of benchmarks (BM) and score functions. In this respect, the Eco-factor tool has borrowed some inspiration from other tools, such as GBTool [8] and MCDM-23 [9].

Regarding the indoor climate score functions CEN CR 1752 [6] is applied. It operates with three pre-defined levels of expectation: A) High, B) Medium, and C) Moderate level of expectation. Category B is applied as "average" (50\%) BM in the indoor climate score functions. A "best possible" benchmark is derived from the ISO 7730 standard [7]. For instance, in Fig 2 the upper BM is chosen as $5 \%$ PPD (Predicted Percentage of Dissatisfied), since it is practically impossible to achieve better results, due to variation of thermal preferences in the population.

The Eco-factor has been developed mainly with design in mind, but it is intended that it can be used also

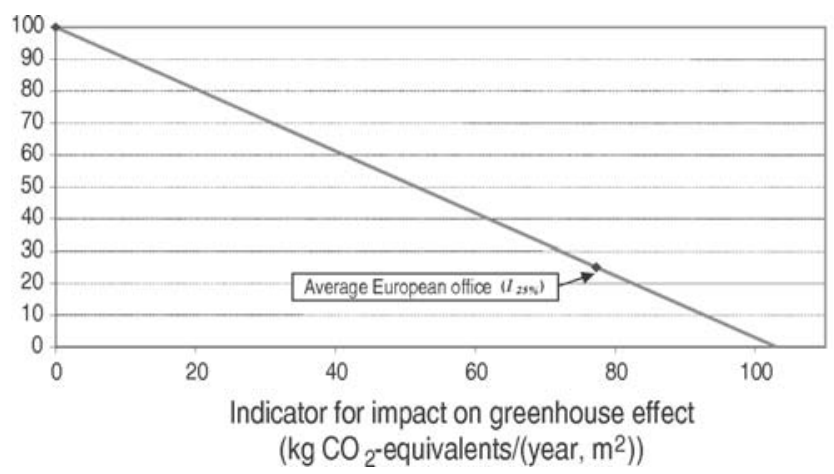

Fig 2. Left: Score function for overall thermal state of the whole body with indicator PPD. Right: Score function for the energy use. The average energy related impact of European office buildings is used as $25 \%$ BM. Zero emission is chosen as $100 \%$ BM (best possible) 
for environmental optimisation of choices made in the operation phase. The building designers have different needs at different stages of the design process. Often, for the first assessment, one is satisfied with viewing overall scores that are synthesised from a number of inputs. Later, a more detailed information about individual categories can help making clear cause-effect relationships, and showing possibilities for improvement. For this reason, the Eco-factor tool is defined so that input can be based on both simple and advanced calculations in early and later phases of design, respectively.

\subsection{Assessment methods}

The Eco-factor tool contains a number of options that allow the user to modify the "interpretation" of the basic data regarding energy related emissions. The energy assessments in this paper are based on the greenhouse effect only (meaning $\mathrm{CO}_{2}$ equivalents). The tool includes three other methods for assessing: EPS [10], Eco-indicator 99 [11] and "Acidification" (mole $\mathrm{H}^{+}$ equivalent). The tool also includes an option to modify the default 50/50 weighting of indoor climate and energy impacts to either an "authoritative panel" type weighting or a user-defined weighting.

Since the production of nuclear energy produces very few emissions directly to air, electricity produced by nuclear energy automatically receives a good "score", since the environmental assessment is made solely on the airborne, energy-related emissions. This may seem "unfair" to many people, since nuclear energy may constitute a risk in other terms. In order to cope with that, the so-called "low-priority factor" is applied. Using the low-priority factor the user can "scale" the impact of eg nuclear energy. In any case, the low-priority factor can be used experimentally to receive an impression of the importance of this choice. If little nuclear energy is used, the matter becomes negligible. For a further discussion of this, see [2].

\subsection{Definition of cases}

To illustrate the use of the Eco-factor in the design process, simplified, steady-state models are applied for calculating input data. It is chosen to look at alternative designs of a - theoretical - three-story naturally ventilated office building located in Denmark. Two basic building layouts are chosen with rather different thermal characteristics, on which some variations of the ventilation principle are investigated. This provides different solutions that may illustrate the importance of some key design choices that must be made quite early in the design process.

The focus of the paper is not on how the results are obtained. They may be generated by various standard calculation methods. Thus, only the overall information and main findings of the two cases are included to con- centrate on the application and interpretation of the Ecofactor tool. The issue in focus is how to evaluate the results.

Case 1 is based on a rather "cautious" or "conservative" design in terms of window area and internal heat loads, meaning that it is relatively easy to comply with thermal comfort standards. Case 2 is based on the same geometry, but where the designers and the owner have gone more to the limits, by having very large glazed facades and by allowing more occupants. We consider this a more "incautious" or even slightly "reckless" design in terms of thermal comfort, but, unfortunately, not altogether untypical of contemporary office design.

In both cases we have chosen to assume that shading is supplied in summer when needed, with a value equivalent to internal, light curtains - since this is relatively inexpensive and also easy to maintain. It is preferable also for daylighting purposes for the occupants to have manual control of the solar shading, to avoid glare problems. It is also preferable that the shading allows diffuse light to pass through, since heavy shading will result in more use of artificial lighting, which carries a penalty in terms of energy use.

Temperature calculations with simplified tools have been applied (steady-state heat balance with correction for thermal mass), together with energy data based on empirical data for a new, naturally ventilated office building on a Danish location. This choice of data sources can illustrate the use of the Eco-factor tool in an early design phase, where many decisions are preliminary and where one is not interested in allocating large resources on advanced calculations. It is assumed possible in both cases to maintain optimal operative temperatures in wintertime; thus, it is mainly a warm summer situation that is considered with regard to thermal comfort. The aim is that it should be possible to maintain thermal comfort without the use of electrical energy for cooling purposes. An air change rate of $10 \mathrm{~h}^{-1}$ is chosen as an upper acceptable limit under consideration of draught risk.

\section{Eco-factor results}

The Eco-factor tool contains auxiliary calculation procedures to determine the discomfort indicators from user-input data (example in Fig 3). On the basis of the discomfort indicators, a score is calculated in each category (Fig 1). Results are given in Figs 4 and 5 for both cases.

Apart from the already reported indoor climate data, the following energy data is supplied as shown in Fig 6 .

Fig 7 shows the output from the Eco-factor tool where the total Eco-factor $(62,1 \%)$ is calculated. The total Eco-factor is visualised as a "pie" comprising an energy part to the left and an indoor climate part to the right. Here the contributions to the total Eco-factor from energy use (39\%) and from indoor climate $(23 \%)$, respectively, are clearly shown. At the same time it is 


\begin{tabular}{|c|c|c|}
\hline \multicolumn{3}{|l|}{$\begin{array}{l}\text { Overall thermal balance } \\
\text { Necessary physical parameters, ISO } 7730\end{array}$} \\
\hline Air temperature & $21 \mathrm{C}$ & $\mathrm{PPD}=5,3 \%$ \\
\hline Mean radiant temperature & $21 \mathrm{C}$ & \\
\hline Relative humidity & $50 \% \mathrm{RH}$ & \\
\hline Mean air velocity & $0,1 \mathrm{~m} / \mathrm{s}$ & \\
\hline Clothing insulation & 1 clo & \\
\hline Activity level & 1,2 met & \\
\hline
\end{tabular}

Fig 3. Example of support by the Eco-factor tool to calculate the discomfort indicators. In this example PPD is determined for Case 1, winter based on a number of physical parameters like the air temperature etc
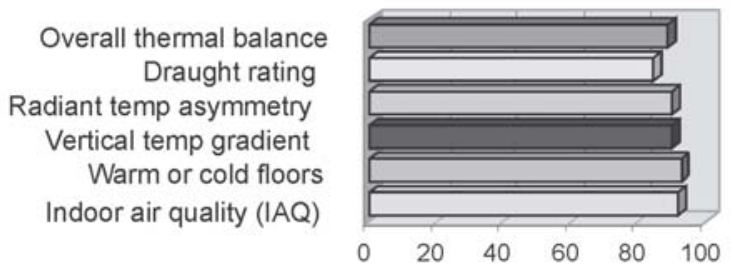

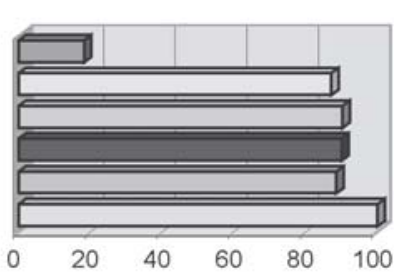

Fig 4. Indoor climate scores for the summer case (100\% corresponds to best possible). Case 1 left, Case 2 right
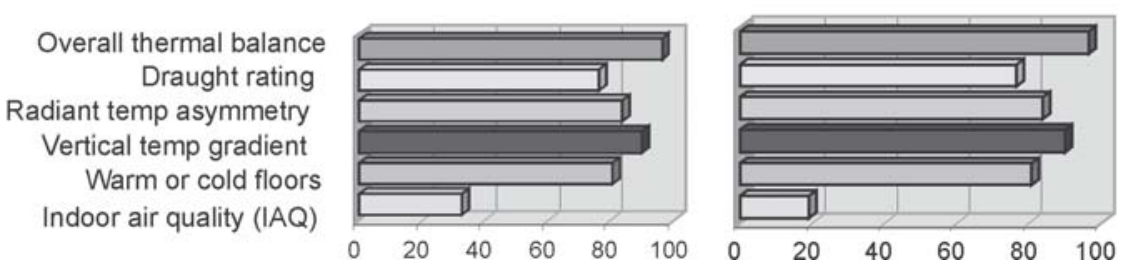

Fig 5. Indoor climate scores for the winter case (100\% corresponds to best possible). Case 1 left, Case 2 right

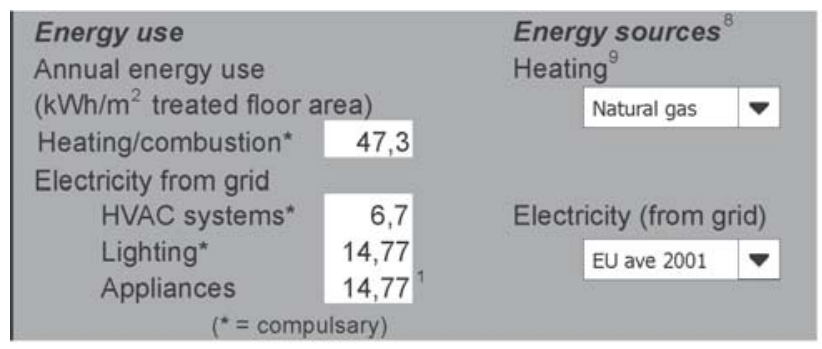

\begin{tabular}{|c|c|}
\hline \multirow{2}{*}{\multicolumn{2}{|c|}{$\begin{array}{l}\text { Heatıng/combustion" } \\
\text { Electricity from grid }\end{array}$}} \\
\hline & \\
\hline HVAC systems & 6,7 \\
\hline Lighting* $^{*}$ & 14,77 \\
\hline Appliances & 22,15 \\
\hline
\end{tabular}

Fig 6. Energy use and source input required by the Eco-factor tool. The energy source is chosen from a "drop-down" list of typical energy sources. Energy use for Case 1 is based on empirical data. Small picture, right: energy use for Case 2

Eco-factor $=62,1 \%$

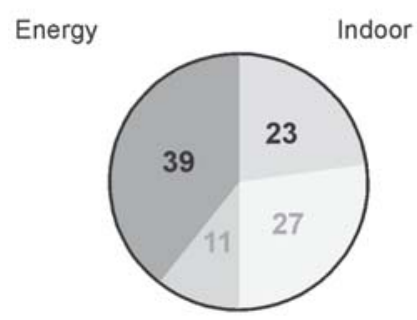

Improvement potential

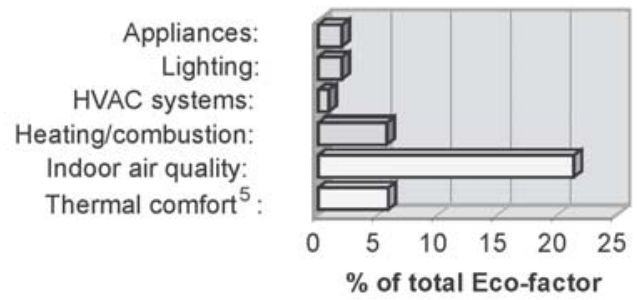

Fig 7. Output of Eco-factor tool: Eco-factor score distributed on energy and indoor climate performance, respectively; and the so-called Improvement potential. Example: Case 1, winter 
visualised how far the two core Eco-factors are of maximum value. In that way the tool also constitutes a communication means for non-experts.

A so-called "improvement potential" (IP), Fig 7 on the right, is intended as a guide to the designer as to where attention should be focused, a so-called "ranking" capability. The IP tells the designer where the "missing" points (shown in lighter colours on the pie chart) can be found. In this case, it is found that the building is doing quite well, except that the IAQ is poor. One way of improving the situation would be to increase the air change rate. This would, however, have some consequences with regard to heat loss. This is more of a problem in case of natural ventilation, since a heat exchanger can be used in a mechanical system, which, however, uses fan energy.

Case 1 achieves a very good score in summer and an acceptable score in winter (Figs 4, 5). Thermal comfort seems to be quite consistent throughout the year, while IAQ shows a large seasonal variation, with quite a low score in wintertime. Case 2 mainly has a problem with thermal comfort in summertime, despite very large air change rates, which might be impossible to obtain by natural ventilation, at least much of the time.

For this reason Case 2 is abandoned, and focus is now on optimising Case 1 solving the IAQ problems in winter (Fig 8). A possible approach is to apply a different air distribution principle, for instance, displacement ventilation instead of conventional mixing ventilation, since this has no negative influence on the heat balance. On the contrary, in case of mechanical ventilation, the improved temperature effectiveness of displacement ventilation can be a benefit, if heat recovery is used. However, since natural ventilation is applied, the energy use is assumed to remain constant. Using displacement ventilation increases the ventilation effectiveness and, thus, improves the IAQ for a specific air change rate compared with mixing ventilation. Apart from changing the ventilation principle, the air change rate is increased during office hours.

The above results, based only on simplified calculation models combined with empirical data, clearly reveal that it is a good idea in this case to use displace- ment ventilation, and that an air change rate in office hours is approximately twice, the size of the building regulation requirements would be a net benefit. In a later design phase, the negative influence on the heat balance of increased ventilation can be minimised by choice of control strategy and control parameters, components etc. It may even be considered to use mechanical ventilation or hybrid ventilation with heat recovery. To minimise installation costs, space requirements, and fan use, it would be perhaps possible to apply the mechanical system only in the wintertime and rely on natural ventilation in summertime, thus combining benefits of both systems (hybrid ventilation). In the above examples, a very simple way of reducing heat loss would obviously be to improve the $U$-value of the glazing reducing draught risk due to cold down-draught at the same time - both of them improving the Eco-factor.

\section{Discussion of cases}

The case studies show that some very fundamental design choices regarding window area, occupancy (person $/ \mathrm{m}^{2}$ ), and air change rates, have a profound influence on the indoor climate, on the technical measures that must be taken in order to control the indoor climate, and on the energy consumption needed for these measures. Thus, the importance of these choices in an environmental context must be not underestimated.

An often-mentioned precaution is that of keeping a moderate window size, such as in Case 1 in this paper. The window area should be large enough and sufficiently well distributed that proper daylighting can take place. It is, of course, also - in principle - a benefit to use passive solar heating in the wintertime. This is, however, not the main concern in most modern office buildings, since the heating demand in daytime is typically low, even in winter, due to high internal heat loads and well insulated constructions. In addition, direct solar radiation will often create glare problems, which are most unwanted in an office environment. Instead, it is of the greatest importance to reduce solar radiation and internal heat gains in summertime to a level where overall thermal comfort can be maintained.
Eco-factor $=76,4 \%$

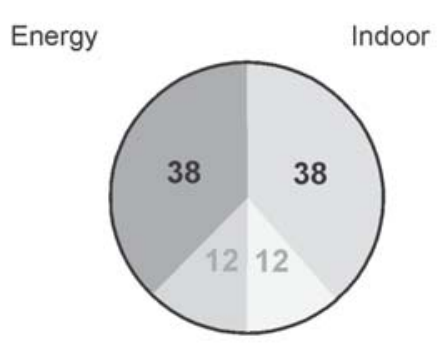

Improvement potential

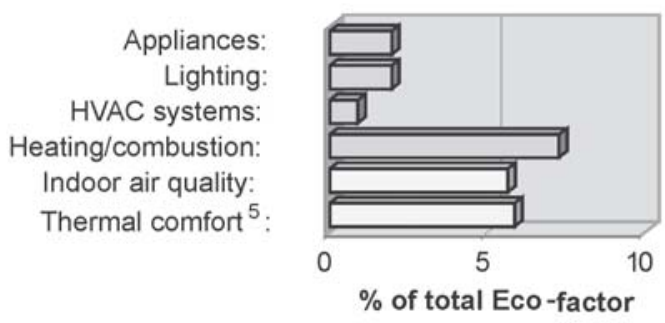

Fig 8. Case 1 improved by changing to the displacement ventilation principle (instead of mixing ventilation) and by using a higher air change rate in office hours only (twice the original level), the overall situation has improved quite a lot, and the detrimental effect on the energy balance is negligible 
Disregarding this kind of advice, such as in Case 2, generates much more demanding requirements on the technical systems, which will invariably increase costs for both construction and energy use (mainly for fans). In addition, large ducts, external shading etc will often be seen by the architect as unwanted restrictions or intrusions. Thus, a certain architectural limitation on one issue (window area) may lead to a larger architectural freedom in some other ways (technical systems). In Case 1 , for instance, it would be possible to rely on natural ventilation only. This is much less likely in Case 2, meaning that a rather large ventilation system must be used.

This does not mean that large window areas are never possible, which recent architectural achievements have proven. It should also be mentioned that some more sophisticated types of windows and glazed facades have not been investigated in this work, which might solve some of the problems in Case 2. However, such technical possibilities do not change the basic conclusion of before: large window areas demand more advanced technical systems, which can, however, be alleviated to some extent by more advanced structural systems, for instance, high-tech windows. This is also in any case likely to lead to increased cost, but reduce energy use for fan operation.

\section{General discussion and conclusion}

It can be argued that the Eco-factor does not take into account all relevant environmental issues; for instance, the whole issue of building materials is completely disregarded. This is indeed true. It is deliberately chosen to focus on the coordination of indoor climate and energy related environmental aspects, since this is perceived as a key hindrance for progress. It is almost axiomatic that a building cannot possibly be considered sustainable if the issues of indoor climate, energy use for operation, and the resulting emissions through choice of energy sources are not dealt with in a satisfactory way. On the other hand, there is nothing to stop the designers from making further environmental improvements, once a building with a high Eco-factor score is achieved. Other existing LCA-based calculation tools must document that. Having said that, it is a fact that the Eco-factor accounts for the major part of the environmental impact [2] and in that respect it may be considered a very efficient screening tool.

In general, the Eco-factor tool has proved to be a useful decision-making tool, as intended. It is especially valuable for design choices where conflicting goals must be considered simultaneously. The goals could typically be related to the balance between costs (energy use) and benefits (indoor climate); for instance, heating energy vs improved IAQ. By giving an interpretation of the total energy related environmental load compared with the quality of the service (good indoor climate) on the same, easily understandable $0-100 \%$ scale, the tool removes much uncertainty and confusion from the decision process.

It is important that the Eco-factor score is not perceived in a static way, as an "once and for all" judgement (as in, for instance, a public labelling scheme), but rather used dynamically in an iterative fashion. This means that during the design process, the Eco-factor score is constantly changing. A low score does not automatically mean that a design suggestion is doomed, but it gives the design team clues as to what should be improved. The issues may change in importance throughout the process, and the Eco-factor gives an opportunity to decide the right time to shift the attention and resources from one issue (eg heating energy) to another (eg indoor air quality).

The Eco-factor provides an easily understandable synthesis of a number of design parameters, which can otherwise be very difficult to compare quantitatively and to rank in terms of importance without rather lengthy and elaborate discussions. This may other things being equal facilitate the communication between the different parties in the building process. The Eco-factor tool supplies a guideline as to where one should focus attention. It is found, by the work done on these and other case studies, that the tool has proven very easy to work with, and offers a great support in pointing out the crucial focal points of the building designs in question.

\section{Acknowledgements}

This paper is based on research produced within the research project IDEEB (Intelligently Designed Energy Efficient Buildings). IDEEB is partly financed by the European Commission within the 5th Framework Programme, ENERGIE.

The Eco-factor tool can be ordered free of charge upon request by e-mail: hb@bt.aau.dk

\section{References}

1. Bjørn, E. and Brohus, H. The „Eco-factor“, a design oriented environmental assessment tool. The Worldwide CIBSE/ASHRAE Gathering of the Building Services Industry, Edinburgh, UK, 24-26 Sept, 2003.

2. Bjørn, E.; Wahlström, A. and Brohus, H. Eco-factor method, IDEEB Report No 2, ISBN 91-7848-974-1, SP Swedish National Testing and Research Institute, Sweden, Jan 2004.

3. Brohus, H. and Bjørn, E. An iterative assessment concept for building design based on the Eco-factor. Journal of Civil Engineering and Management, Vol 12, No 1, 2006, p. 51-56. ISSN 1392-3730.

4. Wahlström, A. and Brohus, H. An Eco-factor method for assessment of building performance. In: Proceedings of the $7^{\text {th }}$ Nordic Building Physics Symposium 2005, Reykjavik, Iceland, June 13-15, 2005. 
5. Cole, R. and Kernan, P. Life-cycle energy use in office buildings. Building and Environment, Vol 31, No 4, 1996, p. 307-317.

6. CEN CR 1752. Ventilation for buildings - design criteria for the indoor environment, CR 1752:1998, CEN Dec 1998.

7. ISO-7730. Moderate thermal environments - Determination of the PMV and PPD indices and specification of the conditions for thermal comfort, 1991, International Standards Organisation, Geneva.

8. Cole, R. J. and Larsson, N. K. GBC '98 and GBTool: Background. Building research and information, Vol 27, Issue 4-5, 1999, p. 221-229. ISSN 09613218.
9. Balcomb, D.; Andresen, I. and Aggerholm S. (eds). Multicriteria decision-making. MCDM-23. A method for specifying and prioritising criteria and goals in design. IEA Solar Heating and Cooling, Task 23: Optimisation of Solar Energy Use in Large Buildings. Draft version, Oct 12, 2001.

10. Steen, B. A systematic approach to environmental priority strategies in product development (EPS). Version $2000-$ Models and data of the default method, CPM report 1999:5, Chalmers University of Technology, Environmental Systems Analysis, 1999.

11. Goedkoop, M. and Spriensma, R. The Eco-indicator 99, A damage oriented method for life cycle impact assessment, Methodology report. Second edition, 17 Apr, PRé Consultants B.V., Amersfoort, The Netherlands, 2000.

\section{BENDRASIS ADMINISTRACINIŲ PATALPŲ MIKROKLIMATO IR ENERGIJOS SĄNAUDŲ IVERTINIMAS NAUDOJANT ECO VEIKSNI}

\section{E. Bjørn, H. Brohus}

\section{Santrauka}

Norint palengvinti sprendimų prièmimą ir ryšių palaikymą, buvo panaudotas vertinimo metodas, kuris absoliučiojoje skaleje nuo 0 iki $100 \%$ ịvertina šiluminès energijos vartojimo ir patalpos komforto palaikymo įtaką aplinkai. Šis veiksnys vadinamas ECO veiksniu. Jis remiasi fizinių savybiu rodikliais. Patalpos mikroklimato pagrindiniai rodikliai yra patalpos temperatūra, oro greitis ir teršalų koncentracija. Energetinè dalis nagrinèja, kaip pasiskirsto energija šaltiniuose, o aplinkosauginè dalis nustato oro taršą gyvavimo ciklo analizès metodu (duomenų bazėje pateikiamos standartinès schemos). Ši priemonė taikoma pastato dizaino kokybės alternatyvoms vertinti, kur ,išlaidos“ (energija) yra lyginamos su „pelnu“ (komforto sąlygomis), ir galimybèms identifikuoti. Čia bus pateikiama administracinio pastato modelio analizè, kai sprendimai priimami ankstyvojoje projektavimo stadijoje.

Raktažodžiai: vertinimo priemonė, patalpos mikroklimatas, energijos sąnaudos, integruotasis projektavimas, itaka aplinkai, sprendimų prièmimas, ECO veiksnys.

Erik BJØRN. Research Associate at the Dept of Civil Engineering, Aalborg University, Denmark. He holds a MSc and $\mathrm{PhD}$ in Indoor Environmental Engineering. Research interests: indoor climate and energy consumption, sustainable building design, LCA and environmental modelling.

Henrik BROHUS. Assoc Prof at the Dept of Civil Engineering, Aalborg University, Denmark. He holds a MSc and $\mathrm{PhD}$ in Indoor Environmental Engineering. Research interests: indoor climate and energy consumption, sustainable building design, advanced building simulation, computational fluid dynamics and stochastic modelling. 